\title{
Medical Record Keeping in the Summer Camp Setting
}

Laura Kaufman'; Jaycelyn Holland²; Stuart Weinberg'2,3; S. Trent Rosenbloom²,34

${ }^{1}$ School of Medicine, Vanderbilt University Medical Center, Nashville, TN, USA;

2Department of Pediatrics, Vanderbilt University Medical Center, Nashville, TN, USA;

${ }^{3}$ Department of Biomedical Informatics, Vanderbilt University Medical Center, Nashville, TN, USA;

${ }^{4}$ Department of Medicine, Vanderbilt University Medical Center, Nashville, TN, USA

\section{Keywords}

Documentation, summer camp, infirmary, informatics, medical record

\section{Summary}

Background: Approximately one fifth of school-aged children spend a significant portion of their year at residential summer camp, and a growing number have chronic medical conditions. Camp health records are essential for safe, efficient care and for transitions between camp and home providers, yet little research exists regarding these systems.

Objective: To survey residential summer camps for children to determine how camps create, store, and use camper health records. To raise awareness in the informatics community of the issues experienced by health providers working in a special pediatric care setting.

Methods: We designed a web-based electronic survey concerning medical recordkeeping and healthcare practices at summer camps. 953 camps accredited by the American Camp Association received the survey. Responses were consolidated and evaluated for trends and conclusions.

Results: Of 953 camps contacted, 298 (31\%) responded to the survey. Among respondents, 49.3\% stated that there was no computer available at the health center, and $14.8 \%$ of camps stated that there was not any computer available to health staff at all. $41.1 \%$ of camps stated that internet access was not available. The most common complaints concerning recordkeeping practices were time burden, adequate completion, and consistency.

Conclusions: Summer camps in the United States make efforts to appropriately document healthcare given to campers, but inconsistency and inefficiency may be barriers to staff productivity, staff satisfaction, and quality of care. Survey responses suggest that the current methods used by camps to document healthcare cause limitations in consistency, efficiency, and communications between providers, camp staff, and parents. As of 2012, survey respondents articulated need for a standard software to document summer camp healthcare practices that accounts for camp-specific needs. Improvement may be achieved if documentation software offers the networking capability, simplicity, pediatrics-specific features, and avoidance of technical jargon.

\section{Correspondence to}

Laura Kaufman, MD

34 Haverhill St

Lawrence, MA 0184

Email: laura.kaufman@glfhc.org
Appl Clin Inform 2016; 7: 1154-1167

http://dx.doi.org/10.4338/ACl-2016-06-RA-0098

received: June 21, 2016

accepted: October 9, 2016

published: December 14, 2016

Citation: Kaufman L, Holland J, Weinberg S, Rosenbloom ST. Medical record keeping in the summer camp setting. Appl Clin Inform 2016; 7: 1154-1167

http://dx.doi.org/10.4338/ACI-2016-06-RA-0098

Funding

Vanderbilt University School of Medicine. 


\section{Background And Significance}

According to the American Camp Association (ACA), approximately 10 million children attend residential overnight camp in the United States each summer [1]. This represents approximately 1 in every 5 children between ages 5 to 17 [2]. Many of these children require healthcare while at camp [3], a need that has grown increasingly complex as more children receive treatment for chronic illnesses with medications [4-6]. For example, a drug trend study by Medco Health Solutions in 2009 revealed that 1 in 4 insured children in the United States, and nearly 30\% of adolescents aged 10-19, were taking at least one prescription medication to treat a chronic health condition [7]. Children were the leading growth demographic in the pharmaceutical industry that year, with rates forecasted to continue to rise [7]. Managing chronic and acute illnesses requires communication among primary care providers, guardians, schools and subspecialists throughout the year [8-10]. Moreover, medical and health records systems needed to facilitate this communication in pediatrics require certain unique features that prevent practitioners from simply adopting lessons from adult documentation practices [11-14].

Geographical separation from established support networks complicates healthcare delivery at residential summer camps. Children at summer camps spend time with new caregivers and are subject to frequent handoffs and transitions as camp health staff members rotate throughout a season $[15,16]$. As a result, the American Academy of Pediatrics recommends that parents, primary providers, camp administrators, and camp healthcare providers openly share information about campers' health conditions and treatment plans [1]. The ACA accreditation standards make generalized recommendations for handling health information adequately to manage campers' chronic conditions and medication needs, as well as treat any additional camp-specific illnesses and injuries [17]. These standards do not specifically assess the efficacy of camp healthcare documentation, handovers, and information-sharing practices. Furthermore, the 'wilderness' setting of camp may limit access to technology, and communication with physicians before and after camp is often left up to parents [15]. Reliable documentation facilitates these transitions in care.

Prior research about residential summer camps has generally been limited to specific camps or regions $[18,19]$ or to questions about illness and injury rates $[3,19,20]$ or disease outbreaks [20]. While numerous guidelines exist with recommendations on health records keeping at camps, such as the content of health screening forms [15], there is little research evaluating how camps manage and use health records $[15,17,18]$. This paper offers insight into how modern summer residential camps record and use camper health information, the impact this has on clinic efficiency and their current practices regarding sharing information with primary caregivers.

\section{Objectives}

To survey residential summer camps for children to determine how camps create, store, and use camper health records. To raise awareness in the informatics community of the issues experienced by health providers working in a special pediatric care setting.

\section{Methods}

\subsection{Overview}

This study evaluated responses from a survey sent to a random selection of residential summer camps in the United States to measure their health records keeping infrastructure and practices. We distributed the survey using an online survey tool [21] via email addresses curated by the American Camping Association (ACA). The authors analyzed responses to quantify methods responding camps use to manage information about the healthcare they provide to campers, and to determine the consistency and limitations of these practices. 


\subsection{Survey Development}

We reviewed ACA standards for health records keeping to compile a list of draft survey items measuring summer camps' medical documentation practices. Items addressed documentation of health screenings, acute and scheduled visits, trip physicals, care outside the health center, medication administration, and parent communication. Examples were provided for offsite situations, including response to a bee-sting or an injury on a hiking trip. The survey ended with 5-point scaled questions and open-ended questions about the respondent's satisfaction with a camp's current recordkeeping practices. The survey also gathered general information about a camp, such as size and affiliation. ACA officials who make site visits to accredited camps reviewed the draft survey items for relevance to accreditation standards and face validity. We programmed the survey into REDCap (Research Electronic Data Capture, http://project-redcap.org), a research support tool developed at Vanderbilt and now used internationally to allows investigators to deliver secure online surveys [21].

\subsection{Survey Dissemination}

The ACA provided primary contact email addresses for 1505 residential summer camps curated in their database. After removing duplicates and technically invalid email addresses, we selected a random sample of 1053 camps, 70\% of the total. Upon obtaining approval from the Vanderbilt IRB, we distributed the survey. For cases where we had no responses or for email bounce-backs, we researched camp websites and the ACA database to find alternate email addresses. We sent the first invitation emails in August 2010, with repeat invitations sent to non-responders again in September 2010, March 2011, June 2011, and July 2012. We included multiple times of year in order to account for the seasonality of camp administration. Our invitation requested that the survey be filled out by a staff member most able to complete it accurately.

\subsection{Analysis}

We generated summary and descriptive statistics using REDCap's data management tools. We illustrate Likert-scale satisfaction questions using diverging stacked bar charts [22]. For unstructured items measuring objective data, such as the name of the commercial software in place, we report raw data. For unstructured items measuring qualitative data, such as beliefs about healthcare delivery at camp, we reviewed responses for common themes, made a list of the most commonly mentioned topics and manually recorded the frequency of comments or complaints about each topic. We report these frequencies and present representative quotes.

\section{Results}

Of the 1053 email addresses in our random sample, we identified 46 duplicate and 150 invalid email addresses. We found 96 alternate email addresses for invalid email addresses, resulting in a total of 953 camps contacted. Among these, 298 responded (31.3\% response rate). Among respondents, 40 (13.4\%) camps submitted partially completed surveys. $>$ Table 1 presents general information about responding camps. Among respondents, $77.2 \%$ came from camp administrators. Among healthcare personnel filling out the surveys, $62.1 \%$ were nurses. The majority of camps that responded included week-long sessions among their session offerings (67.3\%), and $43.9 \%$ offered sessions of 4 or more weeks. Backgrounds of health center staff are illustrated in $>$ Figure 1, and their access to computers and internet is shown in $>$ Table 1 . While many camps did not have a computer in the health center, among those that did, the mean number of health center computers was 1.46 , with a maximum of 10 at one camp. Among the 44 camps serving campers with special needs, $73 \%$ had computers in health centers, while among 238 non-special-needs camps, $47 \%$ had computers.

Camps responding to the survey used different methods to document the diverse settings in which campers receive medical care ( Table 2) with many camps using multiple parallel methods, such as both a log binder and camper health forms to document medications. Depending on event type and location, camps differ in who documents care and when they do so ( $\$$ Table 3 ). Settings of 
care ranged from routine medication administrations to off-property injuries. In addition to the answer choices provided for forms of documenting care, several respondents also wrote in "incident report" as a common format. Among camps documenting using computers, only $10 \%$ named a specific software used. The most common software used was CampMinder, used in 9 camps, followed by CampDoc, used in 5 camps. Other software used were ProCamp, Bunk-1 DB, Microsoft Word, Microsoft Excel, Microsoft Access, Access Database International, Filemaker Pro, or custom systems.

Over $95 \%$ of camps reported performing pre-camp health screenings. Screenings most frequently included medication review (91.1\% of camps). Over 70\% included changes in health history information, special needs, evidence of injuries, and disease screening. Screening for specific disease most often included questions about lice, in $78.1 \%$ of responding camps that include screening. Respondents also screened for skin conditions such as athlete's foot, rashes, and signs of communicable illnesses such as common cold, fever, flu symptoms, or recent sick contacts. Under "other", certain camps mentioned including dietary concerns, tetanus immunization history, and activity levels in their health screenings.

When asked about information included in health and medical documentation, camps reported that acute and scheduled visits and trip physicals included the date, time, visit reason, and staff initials in greater than $95 \%$ of cases, but not all camps consistently included other information such as physical findings. Medication administration consistently included date, name of camper, and medication, seen in greater than $97 \%$ of camps, and $93 \%$ documented administration time, dose, and person administering. Under "other," two camps mentioned including camper initials or signatures. Another camp wrote that medication dosage and description were recorded in lieu of medication name to protect confidentiality.

Scaled responses measuring satisfaction with the camp's methods of completing recordkeeping tasks are illustrated in Figure 2. Respondents were least satisfied with the camp's method of providing parents with documentation of medical care performed during camp. Communication with parents, guardians, and home healthcare providers may occur in pre-camp submission of forms, reports of incidents during camp, and end-of-session summaries of camp healthcare. The ways in which respondents' camps communicated are displayed in Table 4. Methods for these communications included paper, email, direct electronic communication, and phone calls.

Respondents described opinions and recurrent difficulties about their camps' recordkeeping practices in open-ended questions. - Table 5 displays examples of frequent comment categories, and - Table 6 and Table 7 include representative quotes. Among 12 camps desiring improvement in their communication with parents, obstacles included difficulty sharing paper records or miscommunication between administrators about which parents had been called. Some stated they had never considered sending end-of-session reports and others stated this "would be great". One camp noted that parents had been upset about lack of communication and had questioned the camp's documentation practices.

The most frequent complaints regarded the amount of time it takes to appropriately document care, adequate completion of records, and inconsistent organization. A total 39 respondents expressed that an electronic record system would be beneficial. Some mentioned that their staff members learn or work on computers in their home jobs and would prefer similar systems at camp. When specified, the most common scenario with difficult recordkeeping was medication administration. Multiple camps noted dramatically increased numbers of children on medications, especially psychiatric, in recent years. Another concern among medically-oriented and non-medically-oriented camps alike was trouble managing medications and blood sugar measurements for diabetic children.

\section{Discussion}

This study presents a picture of how American residential summer camps create, store, and use health information of their campers. Responses also reveal areas for improvement. These include consistency in documentation practices, efficiency, and communication with parents and primary care providers. 


\subsection{Consistency}

Many respondents described poor consistency and accuracy as sources of frustration. They cited discontinuity between record formats, between records in different locations, such as First-Aid kit logs and health center logs, and between years. Similarly, a 2003 study on summer camp accidents suggested that many illnesses were undocumented [23], indicating inconsistent recordkeeping. One possible reason may be variability in medical staff, who rotate frequently. Furthermore, based on our survey a substantial number of medical events are assisted by non-medical counselors and administrators, especially pre-camp health screenings. Several respondents mentioned inadequately trained staff as causes of inaccurate or incomplete records.

The ACA Standards for Camp Accreditation require documentation of health histories and of medical incidents, with the recommended use of a log binder [17]. Accreditation standards only require that camps show an inspector logbooks and explain their recordkeeping protocols, a review that would not reveal the lapses which occur in practice. Based on our survey, most camps strive to document all information required by the ACA, such as date, general description of illness and treatment, and staff initials, but not all camp systems facilitate reliable recording of even these basic data in every single visit. Moreover, the items we found to be least-consistently recorded in health visits are not required by ACA standards but include substantive information such as physical findings, procedure descriptions, and detailed treatment plans.

The Association of Camp Nurses (ACN) Practice Guidelines on Documentation in Day and Resident Camps [24] also make recommendations on the content of records, and they indicate that documentation should contain "consistently factual" information, which is "a source for initial and ongoing nursing services." If the concern expressed by camp nurses and administrators answering our survey is valid, then camps are both not recording consistently factual information, and they do not have systems in place to allow nurses to access this information easily and reliably for ongoing services.

Our results suggest that the most consistently documented events were medication administration and acute visits. However, medication administration was the most commonly listed difficulty in free-response answers, suggesting that camp protocols, which may all emphasize ideal documentation of medications, differ from daily practices. Pediatric care may be especially subject to medication administration errors as children may have more trouble than adults knowing the purpose for their prescription.

\subsection{Efficiency}

The main concern among respondents regarded efficiency, specifically the time required for documentation and the "tedious" tasks that create extra work. Common reasons included needing to document in multiple places and difficulty storing and accessing records. Several mentioned needing entire rooms to house paperwork of past seasons in order to comply with statutory requirements. ACA standards even suggest maintaining records for two years after campers reach adulthood [17]. Accessing records from previous years, or even previous weeks, was described as troublesome due to the number of papers to sort through, which were frequently inconsistent or incomplete. In addition to being burdensome to staff, difficulty accessing records may be a barrier to efficient time-sensitive care in an emergency. For example, due to the rising numbers of children on prescription medications [7], response to an emergency for any camper could require checking recent medication usage and adverse event histories. "Sometimes the camper has a special medical need, and we do not know about it until it is too late," wrote one respondent.

As early as 1998, a study of camps concluded that information documented by camp nurses was inadequate and recommended computerization to ease record access and continuity of care [25], but over a decade later camps have not adopted such practice as a norm. Only 51\% of respondents' health centers had a computer, and only $59 \%$ had internet access. Consequentially, fewer than $10 \%$ of camps used computers to record any type of health visit.

Computers do not necessarily improve efficiency. One camp wrote, "Due to the short timeframe [of camp season], paper records are easier, more secure, and portable." Yet when asked whether an EMR would be beneficial, 55\% of respondents agreed and 30\% were neutral. One wrote, "We do most health care in dining rooms at meals. Laptop or handheld computer documentation that can 
be synchronized with central files would be a great help." Without prompting, 39 expressed desire for an electronic system, but many also discussed limitations such as cost, internet speed, ease of use, or lack of available software that would efficiently meet their needs without adding extra work.

\subsection{Communication}

The AAP recommends that parents and physicians work together to provide clear, detailed medication instructions for unfamiliar providers [26], and that camps have clear protocols for parental notification of medical events [1]. While little research in this field exists, an early study found communication between parents, physicians, and camps to be inadequate [16], findings which our study reproduces. Survey respondents generally indicated agreement, although not strong agreement, regarding satisfaction with their camps' recordkeeping, but the largest disagreement was in satisfaction with methods to communicate with parents. Some respondents wrote they had never thought of sharing records at camp's end, while others agreed with its appeal but wrote that it would be impractical with their current infrastructure. Only $24 \%$ of camps did share end-of-session documents with parents, and only $11 \%$ shared information with primary care providers. Also notable was the tendency to share information with parents by paper. While this practice is not new, it may appear increasingly outdated to parents in a world of new guidelines concerning privacy of health information [27] and increasing electronic documentation [12, 28].

A 2008 report on pediatric health information technology identified transitions of care as a key error-prone process [11]. The transition to and from residential camp should be treated no more lightly than any other care transition. Future research questions may even ask pediatricians how often they communicate with summer camps, either before or after a session, and whether they wish they did so more frequently. Because campers or even parents may not be able to reliably explain camp health events, primary care pediatricians may lack essential information in providing optimal care to their patients.

\subsection{Improving Documentation [12, 28].}

While increasing EMR use has not necessarily resulted in improved productivity [12], it is apparent that some camps could benefit from digital storage or support, yet they lack a suitable standard method. While some camps identified camp-specific software in use, none stood out as sufficient for the needs of all camps, and many others wrote that no available software meets their requirements $(\triangleright$ Table 7$)$. Responses revealed certain requirements for such a program:

1. Offer, but do not require, internet accessibility. While some camps will benefit from internet both for sharing across camp property and for securely sharing with parents, it cannot be a requirement of a camp software. Many camps do not have reliable, or any, access to internet and still wish to adopt electronic health records. An ideal EMR would have an optional offline mode which could be utilized by camps in poorly connected rural areas.

2. Optimize simplicity: Users will rotate often, will have minimal time to train, and will tend towards shortcuts due to pressure to see many campers quickly. Camp EMRs will not have many of the same billing and regulatory requirements as mainstream pediatric EMRs, and should instead be structured with a goal of optimizing transitions between rotating, and sometimes novice, staff.

3. Avoid unnecessary technical medical jargon: Formats must be standardized enough to be understood by health services providers of different backgrounds.

4. Adopt pediatrics-specific features: These may include tools for calculating pediatric medication dosages or immunizations checklists on health screenings forms. Such features are not only convenient perks; they are crucial for functionality and safety of pediatric medical record systems [11-14].

If such software were developed, a more universal usage would allow improved sharing of information between camps, pending permission from guardians. Assuming many campers attend multiple summer camps in their lifetimes, the ability of camps to share information could be beneficial for the recordkeeping goals of consistency, efficiency, and communication, as well as identifying health trends [29]. Further, the AAP Committee on School Health's health appraisal guidelines for summer 
camps could be modified to include specific guidelines on the management of medical records and eventual implementation of a network of electronic medical records.

\subsection{Limitations}

Limitations of this study may have skewed its accuracy. Our response rate of $31 \%$ cannot reflect the practices of all summer camps. Factors such as seasonality of camp administration and variability of camp staff are obstacles in studying summer camp practices [30]. While we are able to present characteristics of responding camps, we were not able to compare this to information about all residential camps to determine whether our sample was representative. Additionally, because some questions asked about technology usage, camps with more computer access may be more likely to respond to a web-based survey. However, such a trend would imply that our low percentage of camps using computers to document results would actually be higher than the true amount.

Lastly, because survey results were collected from 2010-2012, responses may not reflect how camps could have changed in the ensuing years. Still, the difference between summer camp and contemporary practices in 2011 suggests that a gap likely still exists today. For example, because summer camps are typically located in rural settings, internet access may lag behind, influencing the adoption of EMRs. Pew research data shows that from 2010 to 2015, while internet access for adults in rural communities increased from $69 \%$ to $79 \%$, it still lags behind that in urban communities, which increased from $78 \%$ to $85 \%$ [31]. While it may not accurately reflect modern trends, this study should serve as a reference for future research in a currently overlooked area of focus in pediatric clinical informatics.

\section{Conclusion}

Summer camps in the United States make efforts to appropriately document healthcare given to campers, but inconsistency and inefficiency may be barriers to staff productivity, staff satisfaction, and quality of care. While further research is needed, as of 2010-2012, survey respondents articulated need for a standardized software to document summer camp healthcare practices that accounts for camp-specific needs. Specific functional goals, which may begin to address the desires of camp staff, include providing optional internet-accessibility, optimizing simplicity, avoiding technical jargon, and adopting pediatrics-specifics. Additionally, the ACA could have involvement in the development of such as software and encourage its use for collaboration of information-sharing between camps.

\section{Clinical Relevance}

While efforts to implement advanced medical record systems are rapidly progressing across the country, one special setting where one fifth of school-aged children spend a significant portion of their time, residential summer camp, has lagged behind. Summer camps could benefit substantially from medical record systems built specifically to suit their needs.

\section{Conflict Of Interest}

The authors declare that they have no conflicts of interest in the research.

\section{Financial Disclosure}

None of the authors has a financial disclosure to disclose.

\section{Human Subjects Protections}

This study is IRB-approved and did not subject any human subjects to harm. Confidentiality was ensured for all survey respondents, and no patients were involved in this research.

\section{Acknowledgements}

We would like to thank the Vanderbilt University School of Medicine for their financial and logistical support.

\section{Abbreviations}

ACA: American Camp Association; AAP: American Association of Pediatrics 


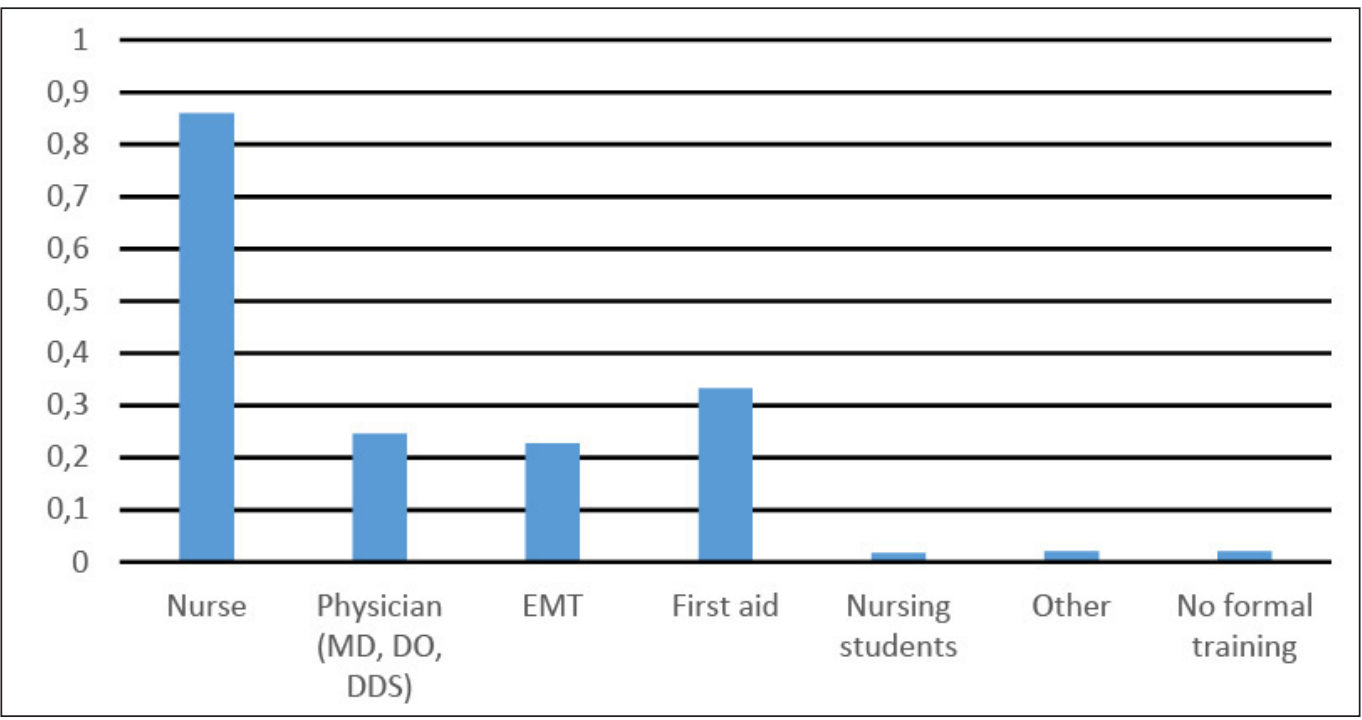

Fig. 1 Titles of staff members working in camp health centers. Survey respondents were given the option to select more than one choice. "First Aid" refers to staff members trained only with first aid certification. Responses for "Other" included Medical Assistants, Emergency First Responders, an athletic trainer, a Certified Diabetes Educator, and Physician Assistants.

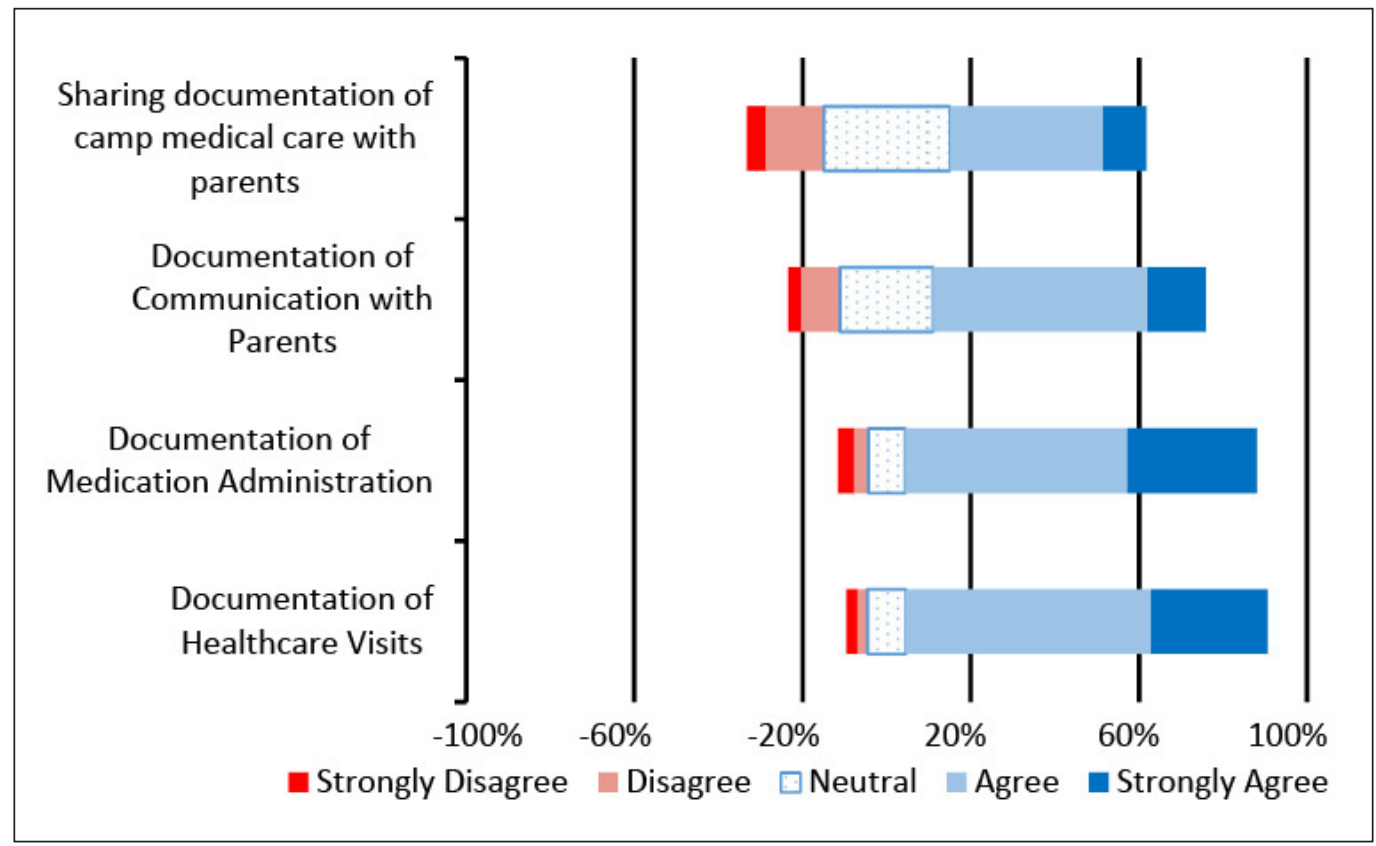

Fig. 2 Answers to 5-point scaled questions regarding respondents' satisfaction with different recordkeeping practices at his or her camp. 


\begin{tabular}{|c|c|c|}
\hline & $\begin{array}{l}\text { Responses } \\
\text { (N) }\end{array}$ & $\begin{array}{l}\text { Percent of } \\
\text { respondents }\end{array}$ \\
\hline $\begin{array}{l}\text { Person filling out survey } \\
\text { - Administrator } \\
\text { - Healthcare worker } \\
\text { - Joint-effort }\end{array}$ & 290 & $\begin{array}{r}77.2 \\
16.6 \\
6.2\end{array}$ \\
\hline $\begin{array}{l}\text { Day camp offered in addition } \\
\text { to residential overnight camp }\end{array}$ & 285 & 27.0 \\
\hline $\begin{array}{l}\text { Camper type } \\
\text { - Boys only } \\
\text { - Girls only } \\
\text { - Co-ed } \\
\text { - Special medical needs }\end{array}$ & $\begin{array}{l}278 \\
278 \\
278 \\
284\end{array}$ & $\begin{array}{r}5.8 \\
18.7 \\
75.5 \\
15.5\end{array}$ \\
\hline $\begin{array}{l}\text { Campers per week } \\
\text { 0-99 } \\
\text { 100-199 } \\
\text { 200-299 } \\
\text { 300-399 } \\
400+\end{array}$ & 283 & $\begin{array}{r}35.7 \\
41.3 \\
9.5 \\
9.2 \\
4.2\end{array}$ \\
\hline $\begin{array}{l}\text { Affiliation } \\
\text { - Agency } \\
\text { - Religiously-affiliated } \\
\text { - Independent non-profit } \\
\text { - Independent for-profit } \\
\text { - Municipal/Government } \\
\text { - Other }\end{array}$ & 282 & $\begin{array}{r}21.3 \\
21.6 \\
33.3 \\
20.2 \\
0.7 \\
2.8\end{array}$ \\
\hline $\begin{array}{l}\text { Computer available } \\
\text { In health center } \\
\text { On property } \\
\text { Internet available } \\
\text { In health center } \\
\text { On property }\end{array}$ & $\begin{array}{l}284 \\
283 \\
285 \\
239\end{array}$ & $\begin{array}{l}50.7 \\
85.2 \\
58.9 \\
98.7\end{array}$ \\
\hline $\begin{array}{l}\text { Type of Internet in health } \\
\text { center, if available } \\
\text { - Wireless } \\
\text { - High-Speed } \\
\text { - Satellite } \\
\text { - Dial-Up } \\
\text { - Not Sure }\end{array}$ & 169 & $\begin{array}{r}69.8 \\
40.2 \\
7.1 \\
3.6 \\
1.8\end{array}$ \\
\hline
\end{tabular}

Table 1 General characteristics of responding summer camps. 
Table 2 Formats of documentation for different healthcare events at summer camp, listed as percent of survey respondents. Respondents were able to choose more than one answer choice for each question represented below. Scheduled visits refer to health center visits with appointments. Trip physicals are health screenings prior to off-site field trips.

\begin{tabular}{|c|c|c|c|c|c|c|c|c|c|c|}
\hline & \multirow{2}{*}{$\begin{array}{l}\text { Total \# } \\
\text { of Re- } \\
\text { spon- } \\
\text { dents (N) }\end{array}$} & \multirow[t]{2}{*}{$\begin{array}{l}\text { Event } \\
\text { Occurs }\end{array}$} & \multirow{2}{*}{$\begin{array}{l}\text { Events which } \\
\text { occur are con- } \\
\text { sistently docu- } \\
\text { mented }\end{array}$} & \multicolumn{7}{|c|}{$\begin{array}{l}\text { Among camps who consistently document the event, what is } \\
\text { the format? }\end{array}$} \\
\hline & & & & $\begin{array}{l}\text { Com- } \\
\text { puter }\end{array}$ & $\begin{array}{l}\text { Health } \\
\text { Form }\end{array}$ & $\begin{array}{l}\text { Note } \\
\text { Card }\end{array}$ & $\begin{array}{l}\text { Files of } \\
\text { Paper }\end{array}$ & $\begin{array}{l}\text { Binderl } \\
\text { Log Book }\end{array}$ & Other & $\begin{array}{l}\text { Not } \\
\text { Sure }\end{array}$ \\
\hline Health Screenings & 278 & $95 \%$ & $89 \%$ & $6 \%$ & $60 \%$ & $4 \%$ & $29 \%$ & $27 \%$ & $3 \%$ & N/A \\
\hline Acute Visits & 279 & $100 \%$ & $100 \%$ & $8 \%$ & $22 \%$ & $1 \%$ & $14 \%$ & $86 \%$ & $3 \%$ & $\mathrm{~N} / \mathrm{A}$ \\
\hline $\begin{array}{l}\text { Medication Ad- } \\
\text { ministration }\end{array}$ & 264 & $100 \%$ & $99 \%$ & $3 \%$ & $18 \%$ & $6 \%$ & $16 \%$ & $80 \%$ & $1 \%$ & $\mathrm{~N} / \mathrm{A}$ \\
\hline Scheduled Visits & 274 & $79 \%$ & $94 \%$ & $7 \%$ & $29 \%$ & $1 \%$ & $17 \%$ & $83 \%$ & $3 \%$ & $\mathrm{~N} / \mathrm{A}$ \\
\hline Trip Physicals & 272 & $28 \%$ & $68 \%$ & $4 \%$ & $45 \%$ & $6 \%$ & $26 \%$ & $53 \%$ & $4 \%$ & N/A \\
\hline $\begin{array}{l}\text { Onsite care out- } \\
\text { side of health } \\
\text { center }\end{array}$ & 255 & $86 \%$ & $94 \%$ & $8 \%$ & $29 \%$ & $9 \%$ & $21 \%$ & $68 \%$ & $9 \%$ & $1 \%$ \\
\hline $\begin{array}{l}\text { Offsite care by } \\
\text { camp-affiliated } \\
\text { provider }\end{array}$ & 243 & $42 \%$ & $87 \%$ & $5 \%$ & $20 \%$ & $17 \%$ & $19 \%$ & $50 \%$ & $10 \%$ & $1 \%$ \\
\hline $\begin{array}{l}\text { Offsite care by } \\
\text { outside provider }\end{array}$ & 251 & $71 \%$ & $97 \%$ & $11 \%$ & $36 \%$ & $2 \%$ & $25 \%$ & $63 \%$ & $11 \%$ & $1 \%$ \\
\hline $\begin{array}{l}\text { Communication } \\
\text { with Parents }\end{array}$ & 264 & $100 \%$ & $87 \%$ & $7 \%$ & $38 \%$ & $2 \%$ & $16 \%$ & $51 \%$ & $8 \%$ & $3 \%$ \\
\hline
\end{tabular}

Table 3 Timing and staff member responsible for documenting different healthcare events at summer camp, listed as percent of survey respondents. Respondents were able to choose more than one answer choice for each question represented below. Empty fields were not asked to camps on surveys.

\begin{tabular}{|l|l|l|l|l|l|l|}
\hline & \multicolumn{3}{|l|}{ Documented at what time(s)? } & \multicolumn{3}{|l|}{ Documented by whom? } \\
\hline & $\begin{array}{l}\text { During the } \\
\text { event }\end{array}$ & $\begin{array}{l}\text { Shortly after } \\
\text { the event }\end{array}$ & $\begin{array}{l}\text { At the end } \\
\text { of day }\end{array}$ & $\begin{array}{l}\text { Medical } \\
\text { staff }\end{array}$ & $\begin{array}{l}\text { Adminis- } \\
\text { trative Staff }\end{array}$ & $\begin{array}{l}\text { Other camp } \\
\text { staff }\end{array}$ \\
\hline Health Screenings & $79 \%$ & $17 \%$ & $9 \%$ & $88 \%$ & $26 \%$ & $12 \%$ \\
\hline Acute Visits & $74 \%$ & $38 \%$ & $6 \%$ & $96 \%$ & $13 \%$ & $4 \%$ \\
\hline Medication Administration & $73 \%$ & $32 \%$ & $3 \%$ & $93 \%$ & $4 \%$ & $4 \%$ \\
\hline $\begin{array}{l}\text { On-property care outside of health } \\
\text { center }\end{array}$ & $33 \%$ & $77 \%$ & $8 \%$ & - & - & - \\
\hline $\begin{array}{l}\text { Offsite care by camp-affiliated pro- } \\
\text { vider }\end{array}$ & $43 \%$ & $63 \%$ & $11 \%$ & - & - & - \\
\hline Offsite care by outside provider & $34 \%$ & $85 \%$ & $9 \%$ & - & - & - \\
\hline Communication with Parents & $62 \%$ & $51 \%$ & $3 \%$ & - & - \\
\hline
\end{tabular}


Table 4 Practices of communicating with parents and home healthcare providers

\begin{tabular}{l|c|c|}
\hline & Responses (N) & Percent of respondents \\
\hline $\begin{array}{l}\text { Parents may submit health forms via: } \\
\text { - Paper } \\
\text { - E-mail }\end{array}$ & 264 & 95.5 \\
\hline $\begin{array}{l}\text { Documentation of calls to parents: } \\
\text { - Document summary of call } \\
\text { - Document the plan discussed }\end{array}$ & 235 & 25.4 \\
\hline $\begin{array}{l}\text { Documentation at end of camp regarding healthcare pro- } \\
\text { vided during camp is sent to: }\end{array}$ & & 88.5 \\
- Parents & & 68.1 \\
\hline - Home healthcare provider & 262 & \\
\hline $\begin{array}{l}\text { End-of-camp healthcare summaries, if provided, use the fol- } \\
\text { lowing means: }\end{array}$ & 261 & 23.7 \\
- Paper \\
- Email \\
- Direct Electronic Communication \\
- Phone Call
\end{tabular}

Table 5 Summary of most frequent comments in open-ended questions to respondents about frustrations or concerns with a camp's medical recordkeeping

\begin{tabular}{|l|c|}
\hline Comment & Frequency \\
\hline \begin{tabular}{l} 
Documentation too time-consuming \\
\hline Parents sending health forms late or not completing at all
\end{tabular} & 55 \\
\hline $\begin{array}{l}\text { Too much work for staff (too many campers to treat or too many tedious steps to documen- } \\
\text { tation) }\end{array}$ & 39 \\
\hline $\begin{array}{l}\text { Lack of recordkeeping continuity } \\
\text { Between record sources (ex: log and files) } \\
\text { Between locations healthcare is given } \\
\text { - Between years }\end{array}$ & 38 \\
\hline \begin{tabular}{l} 
Lack of consistency between frequently-changing health center staff \\
\hline Lack of adequate completion of documents
\end{tabular} & 15 \\
\hline \begin{tabular}{l} 
Technology limits (no internet access, slow internet, power outages, cost of computers) \\
\hline Difficulty accessing campers' prior records from same season due to number of papers
\end{tabular} & 11 \\
\hline Inaccurate records & 35 \\
\hline Inadequate staff competency or numbers & 26 \\
\hline Trouble storing paper records from prior years & 22 \\
\hline Lack of available software to meet camp's needs & 18 \\
\hline Concern about losing records & 16 \\
\hline
\end{tabular}


Table 6 Quotations about practical issues with medical and nursing documentation.

\begin{tabular}{|c|c|c|c|c|c|c|}
\hline Medications & $\begin{array}{l}\text { "We have a large } \\
\text { number of } \\
\text { children who take } \\
\text { meds and it's al- } \\
\text { ways a race to } \\
\text { keep up with the } \\
\text { information." }\end{array}$ & $\begin{array}{l}\text { "As a society } \\
\text { the ridiculous } \\
\text { volume of meds } \\
\text { we have our } \\
\text { kids on." }\end{array}$ & $\begin{array}{l}\text { "Growing number } \\
\text { of campers need- } \\
\text { ing medication, } \\
\text { esp. psych meds." }\end{array}$ & $\begin{array}{l}\text { "Our current rec- } \\
\text { ord is } 153 \\
\text { campers who had } \\
435 \text { separate } \\
\text { medications!" }\end{array}$ & $\begin{array}{l}\text { "Keeping track } \\
\text { of(...) diabetes, aller- } \\
\text { gies, ADHD or other } \\
\text { psychological medi- } \\
\text { cations, and behavior } \\
\text { plans." }\end{array}$ & $\begin{array}{l}\text { "Especially when } \\
\text { [medications] are } \\
\text { given to the health } \\
\text { staff in zip bags } \\
\text { simply labeled ,give } \\
1 \text { of each to my } \\
\text { child every day" " }\end{array}$ \\
\hline Time & $\begin{array}{l}\text { "We will be ad- } \\
\text { ding a health } \\
\text { care secretary } \\
\text { next summer as } \\
\text { paperwork seems } \\
\text { to be a universal } \\
\text { challenge." }\end{array}$ & $\begin{array}{l}\text { "It's a require- } \\
\text { ment and we do } \\
\text { it." } \\
\text { "So time con- } \\
\text { suming" }\end{array}$ & $\begin{array}{l}\text { "Everything moves } \\
\text { so quickly that } \\
\text { they think they'll } \\
\text { do it later but they } \\
\text { forget or they } \\
\text { don't realize the } \\
\text { importance of it." }\end{array}$ & $\begin{array}{l}\text { "Too many kids, } \\
\text { not enough time" } \\
\text { "Tedious" }\end{array}$ & $\begin{array}{l}\text { A frustration is } \\
\text { "keeping up on the } \\
\text { different types of } \\
\text { documentation" }\end{array}$ & $\begin{array}{l}\text { "There are so many } \\
\text { campers that come } \\
\text { in each day that it is } \\
\text { sometimes hard to } \\
\text { organize and keep } \\
\text { track of each } \\
\text { camper's medical } \\
\text { concerns." }\end{array}$ \\
\hline $\begin{array}{l}\text { Pre-camp } \\
\text { communi- } \\
\text { cation }\end{array}$ & $\begin{array}{l}\text { "Change of } \\
\text { medications prior } \\
\text { to arriving to } \\
\text { camp...Lack of } \\
\text { proper labeling of } \\
\text { medications." }\end{array}$ & $\begin{array}{l}\text { "Information } \\
\text { received from } \\
\text { the parents is } \\
\text { not always } \\
\text { timely, accurate } \\
\text { or complete." }\end{array}$ & $\begin{array}{l}\text { "Many parents } \\
\text { state that there are } \\
\text { no meds on the } \\
\text { forms, but then ar- } \\
\text { rive with a bag full } \\
\text { of meds so we } \\
\text { cannot set up the } \\
\text { documentation } \\
\text { ahead of time." }\end{array}$ & $\begin{array}{l}\text { "Parents who do } \\
\text { not send paper- } \\
\text { work ahead of } \\
\text { time and want } \\
\text { the full attention } \\
\text { of the nurses on } \\
\text { opening day." }\end{array}$ & $\begin{array}{l}\text { "Sometimes the } \\
\text { camper has a special } \\
\text { medical need, and } \\
\text { we do not know } \\
\text { about it until it is too } \\
\text { late." }\end{array}$ & $\begin{array}{l}\text { "Lack of clarity from } \\
\text { parents on medical } \\
\text { forms about medi- } \\
\text { cation distribution." }\end{array}$ \\
\hline $\begin{array}{l}\text { Post-care } \\
\text { communi- } \\
\text { cation }\end{array}$ & \multicolumn{2}{|c|}{$\begin{array}{l}\text { "Getting information to parents in } \\
\text { a timely way. Snail mail is not quick } \\
\text { enough for parents anymore." } \\
\text { "Don't always make good judg- } \\
\text { ments as to when parents need to } \\
\text { be notified." }\end{array}$} & $\begin{array}{l}\text { "Would love to } \\
\text { quickly run reports } \\
\text { for parents at the } \\
\text { end of their } \\
\text { camper's stay! } \\
\text { Doing that now } \\
\text { would be a lesson } \\
\text { in frustration since } \\
\text { we're paper- } \\
\text { based." }\end{array}$ & $\begin{array}{l}\text { "The ability to } \\
\text { send home } \\
\text { letters...or gener- } \\
\text { ate emails the } \\
\text { day of visit would } \\
\text { be enormously } \\
\text { helpful." }\end{array}$ & \multicolumn{2}{|c|}{$\begin{array}{l}\text { "Although we do phone parents(...) when } \\
\text { a health issue arises at camp, we do not } \\
\text { have a formal way to keep track of that } \\
\text { communication. We also do not forward } \\
\text { info to the camper's MD." }\end{array}$} \\
\hline Consistency & $\begin{array}{l}\text { "Inconsistency of } \\
\text { detailed informa- } \\
\text { tion depending } \\
\text { on who exactly is } \\
\text { documenting } \\
\text { info." }\end{array}$ & $\begin{array}{l}\text { "Not consistent } \\
\text { from one pa- } \\
\text { tient to another. } \\
\text { It is hard to } \\
\text { track and report } \\
\text { because no- } \\
\text { thing is elec- } \\
\text { tronic." }\end{array}$ & $\begin{array}{l}\text { "Not all entries in- } \\
\text { clude all pertinent } \\
\text { information." } \\
\text { "With volunteer } \\
\text { med staff changing } \\
\text { weekly, consisten- } \\
\text { cy is the biggest } \\
\text { issue" }\end{array}$ & $\begin{array}{l}\text { "We have a great } \\
\text { method in place, } \\
\text { but execution of } \\
\text { the documenting } \\
\text { plan is lacking. }\end{array}$ & $\begin{array}{l}\text { "We have different } \\
\text { nurses each week, } \\
\text { each with their own } \\
\text { process that is not } \\
\text { consistent." }\end{array}$ & $\begin{array}{l}\text { "We utilize } 5-25 \\
\text { medical volunteers } \\
\text { that are different } \\
\text { each session, so } \\
\text { consistency and } \\
\text { simplification is es- } \\
\text { sential." }\end{array}$ \\
\hline $\begin{array}{l}\text { Record lo- } \\
\text { cations }\end{array}$ & $\begin{array}{l}\text { "Because we use } \\
\text { First Aider/WFA } \\
\text { personnel, the } \\
\text { importance of } \\
\text { documentation is } \\
\text { not always recog- } \\
\text { nized(...) and is } \\
\text { often resisted." }\end{array}$ & $\begin{array}{l}\text { "I have wanted } \\
\text { a system where } \\
\text { (...) files could } \\
\text { be accessed on } \\
\text { handheld de- } \\
\text { vices(...) ANY- } \\
\text { WHERE on the } \\
\text { camp property." }\end{array}$ & $\begin{array}{l}\text { "We do most } \\
\text { health care in } \\
\text { dining rooms at } \\
\text { meals. Laptop or } \\
\text { handheld com- } \\
\text { puter documen- } \\
\text { tation that can be } \\
\text { synchronized with } \\
\text { central files would } \\
\text { be a great help." }\end{array}$ & $\begin{array}{l}\text { "The timely re- } \\
\text { turn of orange } \\
\text { [first aid] cards } \\
\text { by staff, which } \\
\text { makes for late } \\
\text { entries and fol- } \\
\text { low up care by } \\
\text { Nurse." }\end{array}$ & $\begin{array}{l}\text { "We have developed } \\
\text { a mobile health care } \\
\text { delivery system } \\
\text { where we can re- } \\
\text { spond to minor } \\
\text { needs quickly and } \\
\text { easily outside of the } \\
\text { clinic, and document } \\
\text { them(...) in a small } \\
\text { note book." }\end{array}$ & $\begin{array}{l}\text { "When we dispense } \\
\text { medications we } \\
\text { usually take the } \\
\text { medications to the } \\
\text { children, where } \\
\text { there is no com- } \\
\text { puter." }\end{array}$ \\
\hline
\end{tabular}


Table 7 Quotations about administrative issues with medical and nursing documentation

\begin{tabular}{|c|c|c|c|c|c|}
\hline $\begin{array}{l}\text { Accessibil- } \\
\text { ity }\end{array}$ & $\begin{array}{l}\text { "Having to store our } \\
\text { PAPER documents in fil- } \\
\text { ing cabinets. We are not } \\
\text { allowed to throw them } \\
\text { away until they turn 18." }\end{array}$ & $\begin{array}{l}\text { "It is hard to have } \\
\text { information in sev- } \\
\text { eral places." } \\
\text { "Information is dif- } \\
\text { ficult to review and } \\
\text { retrieve." }\end{array}$ & $\begin{array}{l}\text { "It's usually filed in } \\
\text { the attic and not } \\
\text { easily accessible" }\end{array}$ & $\begin{array}{l}\text { "Large area } \\
\text { needed for stor- } \\
\text { age of paper for } \\
7-30 \text { years - } \\
\text { boxed by year, } \\
\text { alphabetically, } \\
\text { for } 7 \text { sites." }\end{array}$ & $\begin{array}{l}\text { "We keep all records from the } \\
\text { previous year, but it can be dif- } \\
\text { ficult to find the camper's } \\
\text { health form if the parent } \\
\text { doesn't know which session } \\
\text { they attended." }\end{array}$ \\
\hline Regulations & $\begin{array}{l}\text { "Would like to see all } \\
\text { camper medical informa- } \\
\text { tion... be digital and uni- } \\
\text { versally accepted at all } \\
\text { hospitals." } \\
\text { "Would appreciate it if } \\
\text { ACA could develop a new } \\
\text { system that does not } \\
\text { require so much time." }\end{array}$ & $\begin{array}{l}\text { "Need for forms } \\
\text { that are consistent } \\
\text { throughout the } \\
\text { camping industry } \\
\text { and acceptable to } \\
\text { the medical com- } \\
\text { munity" } \\
\text { "State laws. Insur- } \\
\text { ance difficulties." }\end{array}$ & $\begin{array}{l}\text { "Hospitals(...) not } \\
\text { recognizing insur- } \\
\text { ance forms, not } \\
\text { treating without par- } \\
\text { ent even when we } \\
\text { have signed per- } \\
\text { mission to treat." }\end{array}$ & $\begin{array}{l}\text { "Different fund- } \\
\text { ing sources } \\
\text { require different } \\
\text { documentation } \\
\text { for a camp with } \\
\text { special needs." }\end{array}$ & $\begin{array}{l}\text { "The ACA requires(...) a spiral } \\
\text { bound notebook format. I } \\
\text { would prefer(...) a PCR format } \\
\text { similar to the forms used in } \\
\text { prehospital settings...A stan- } \\
\text { dard form would be beneficial } \\
\text { for uniformity(...) this of } \\
\text { course would have to be ap- } \\
\text { proved by the ACA." }\end{array}$ \\
\hline $\begin{array}{l}\text { Technical } \\
\text { Limits }\end{array}$ & $\begin{array}{l}\text { "Due to the short time- } \\
\text { frame (of our camp sea- } \\
\text { son), paper records are } \\
\text { easier, more secure, and } \\
\text { portable." } \\
\text { "Would love an electronic } \\
\text { documentation system } \\
\text { that does not require in- } \\
\text { ternet access." }\end{array}$ & $\begin{array}{l}\text { "The internet is SO } \\
\text { slow." } \\
\text { "We are consider- } \\
\text { ing going to a com- } \\
\text { puter for all of this } \\
\text { information and } \\
\text { are waiting to hear } \\
\text { how other camps } \\
\text { are doing with it." }\end{array}$ & $\begin{array}{l}\text { "We have satellite } \\
\text { internet and are li- } \\
\text { mited in the amount } \\
\text { of info we can } \\
\text { download/upload." }\end{array}$ & $\begin{array}{l}\text { "If we go to } \\
\text { computer-based } \\
\text { systems, we have } \\
\text { (a) problem with } \\
\text { power outages } \\
\text { and (b) concerns } \\
\text { with retrieving } \\
\text { data many } \\
\text { moons from } \\
\text { now." }\end{array}$ & $\begin{array}{l}\text { "The cost to implement is not } \\
\text { worth the effort to make the } \\
\text { confusion." }\end{array}$ \\
\hline $\begin{array}{l}\text { Electronic } \\
\text { vs Paper } \\
\text { Records }\end{array}$ & $\begin{array}{l}\text { "Have researched many } \\
\text { camp software options, } \\
\text { including Camp Doctor - } \\
\text { and none work for our } \\
\text { medical team." } \\
\text { "MS Access databases } \\
\text { and it's related queries } \\
\text { are a great tool." } \\
\text { "We have found Camp- } \\
\text { Minder to be a wonderful } \\
\text { camp information man- } \\
\text { agement software." } \\
\text { "We would love to have a } \\
\text { solution that would allow } \\
\text { our medical records to be } \\
\text { kept electronically that is } \\
\text { easy to learn and afford- } \\
\text { able." }\end{array}$ & $\begin{array}{l}\text { "I don't see a need } \\
\text { to link our camp } \\
\text { nurse to a com- } \\
\text { puter to electroni- } \\
\text { cally document } \\
\text { everything that } \\
\text { they do. I do see } \\
\text { the need to for } \\
\text { forms to be stream- } \\
\text { lined and elec- } \\
\text { tronic." } \\
\text { "I am used to com- } \\
\text { puter documen- } \\
\text { tation within the } \\
\text { hospital and school } \\
\text { systems I work } \\
\text { with." }\end{array}$ & $\begin{array}{l}\text { "It is very time con- } \\
\text { suming having to } \\
\text { sign and document } \\
\text { on each camper and } \\
\text { counselor health } \\
\text { form, especially } \\
\text { since no one really } \\
\text { pays to much atten- } \\
\text { tion to it. I feel } \\
\text { documentation is } \\
\text { only needed if there } \\
\text { is a health problem } \\
\text { or camper is on } \\
\text { medication." } \\
\text { "It would be won- } \\
\text { derful to implement } \\
\text { a computer based } \\
\text { system rather than } \\
\text { the piles of paper- } \\
\text { work" }\end{array}$ & $\begin{array}{l}\text { "There are some } \\
\text { programs out } \\
\text { there for EHR } \\
\text { and EMR but } \\
\text { were not de- } \\
\text { signed for camp } \\
\text { use, and or not } \\
\text { user friendly or } \\
\text { not flexible so as } \\
\text { to be manipu- } \\
\text { lated by each } \\
\text { user for their } \\
\text { purposes." } \\
\\
\text { "We are a very } \\
\text { small camp, serv- } \\
\text { ing healthy kids, } \\
\text { so...our ,old } \\
\text { school' paper } \\
\text { system works } \\
\text { just fine" }\end{array}$ & $\begin{array}{l}\text { "My handwriting is very poor } \\
\text { and it is difficult for others to } \\
\text { read." } \\
\text { "Online tracking resource with } \\
\text { a local stored copy would be } \\
\text { great." } \\
\text { "Losing or misplacing charts" } \\
\text { "We have so many different } \\
\text { places to document that it can } \\
\text { be easy to make mistakes. We } \\
\text { have tried to create a computer } \\
\text { program ourselves, but it just } \\
\text { wasn't functional to work in } \\
\text { the health center setting." }\end{array}$ \\
\hline
\end{tabular}




\section{References}

1. Health appraisal guidelines for day camps and resident camps. American Academy of Pediatrics Committee on School Health. Pediatrics 2005; 115(6): 1770-1773.

2. US Census Bureau DID. Population Estimates. [cited 2015 Jan 23]; Available from: http://www.census. gov/popest/data/national/totals/2014/index.html

3. The Healthy Camp Study Impact Report. 2010.

4. Van Cleave J, Gortmaker SL, Perrin JM. Dynamics of obesity and chronic health conditions among children and youth. JAMA 2010; 303(901): 623-630.

5. Akinbami LJ, et al. Attention Deficit Hyperactivity Disorder Among Children Aged 5 - 17 Years in the United States , 1998 - 2009. NCHS Data Brief 2011; 70: 1-8.

6. Carroll M, Examination N. Prevalence of Obesity Among Children and Adolescents: United States, Trends 1963 - 1965 Through 2007 - 2008. Children 2010; 17: 1-5.

7. Mathews AW. So Young and So Many Pills. Wall Street Journal 2010 [cited 2016 Sep 20]. Available from: http://www.wsj.com/articles/SB10001424052970203731004576046073896475588

8. Kuo DZ, Sisterhen LL, Sigrest TE, Biazo JM, Aitken ME, Smith CE. Family experiences and pediatric health services use associated with family-centered rounds. Pediatrics 2012; 130(2): 299-305.

9. Hilliard ME, Perlus JG, Clark LM, Haynie DL, Plotnick LP, Guttmann-Bauman I, Iannotti RJ. Perspectives from before and after the pediatric to adult care transition: a mixed-methods study in type 1 diabetes. Diabetes Care 2014; 37(2): 346-354.

10. Coker TR, Moreno C, Shekelle PG, Schuster MA, Chung PJ. Well-child care clinical practice redesign for serving low-income children. Pediatrics 2014; 134(1): e229-e239.

11. Kim GR, Lehmann CU. Pediatric aspects of inpatient health information technology systems. Pediatrics 2008; 122(6): e1287-e1296.

12. Lehmann CU, O'Connor KG, Shorte VA, Johnson TD. Use of electronic health record systems by officebased pediatricians. Pediatrics 2015; 135(1): e7-e15.

13. Anoshiravani A, Gaskin GL, Groshek MR, Kuelbs C, Longhurst CA. Special requirements for electronic medical records in adolescent medicine. J Adolesc Health 2012; 51(5): 409-414.

14. Spooner SA. Special requirements of electronic health record systems in pediatrics. Pediatrics 2007; 119(3): 631-637.

15.Erceg LE. Health Histories: What Are Camps (Not) Asking? CompassPoint 2004; 13(1): 17-23.

16.Lishner K, Busch K. Safe delivery of medications to children in summer camps. Pediatr Nur 1994; 20(3): 249-253.

17. Health and Wellness Standards for Camp Accreditation. American Camp Association; 2010.

18. Walton EA, Maio RF, Hill EM. Camp health services in the state of Michigan. Wilderness Environ Med 2004; 15(4): 274-283.

19. Key JD. Illness and injuries at summer camp. South Med J 1997; 90(5): 489-492.

20. Yard EE, Scanlin MM, Erceg LE, Powell GM, Wilkins JR, Knox CL, Comstock RD. Illness and injury among children attending summer camp in the United States, 2005. Pediatrics 2006; 118(5): e1342-e1349.

21. Harris PA, Taylor R, Thielke R, Payne J, Gonzalez N, Conde JG. Research electronic data capture (REDCap) - a metadata-driven methodology and workflow process for providing translational research informatics support. J Biomed Inform 2009; 42(2): 377-381.

22. Robbins NB, Heiberger RM, Court C, Hall S. Plotting Likert and Other Rating Scales. Jt Stat Meet 2011; m1058-m1066.

23. Elliott TB, Elliott BA, Bixby MR. Risk factors associated with camp accidents. Wilderness Environ Med 2003; 14(1): 2-8.

24. December USVA. Documentation in Day and Resident Camps. 2013; (December): 2013.

25. Rauckhorst L, Aroian JF. Children's use of summer camp health facilities: a longitudinal study. J Pediatr Nurs 1998; 13(4): 200-209.

26. Guidelines for the administration of medication in school. Committee on School Health. Pediatrics 2003; 112(3 Pt 1): 697-699.

27. Bergren MD. HIPAA-FERPA revisited. J Sch Nurs 2004; 20(2): 107-112.

28. Adams WG, Mann AM, Bauchner H. Use of an electronic medical record improves the quality of urban pediatric primary care. Pediatrics 2003; 111(3): 626-632.

29. Hiltz C, Johnson K, Lechtenberg JR, Maughan E, Trefry S. School Nurse Role in Electronic School Health Records. Position Statement. Silver Spring; 2014. Available from: http://www.nasn.org/PolicyAdvocacy/Posi tionPapersandReports/NASNPositionStatementsFullView/tabid/462/smid/824/ArticleID/641/Default.aspx

30. Baird SB, Montejano LB. Roles and Responsibilities Of Seasonal and Year-Round Camp Nurses. CompassPoint 2007; 17(1).

31.Perrin A, Duggan M. Americans' Internet Access: 2000-2015. Pew Research Center; 2015. 